\title{
Oxygen dynamics during in vitro seizures
}

Yina Wei ${ }^{{ }^{*}}$, Ghanim Ullah², Justin Ingram¹, Steven Schiff ${ }^{1,3}$

From Twenty First Annual Computational Neuroscience Meeting: CNS*2012

Decatur, GA, USA. 21-26 July 2012

Oxygen is an essential element for brain activity. The brain is a metabolic engine that requires $20 \%$ of the body's metabolic energy, despite being only $2 \%$ of the human body mass [1]. Two thirds of brain's metabolic energy is dedicated to supporting neural spiking activity. Much of the $\mathrm{O}_{2}$ dependent ATP metabolism in single
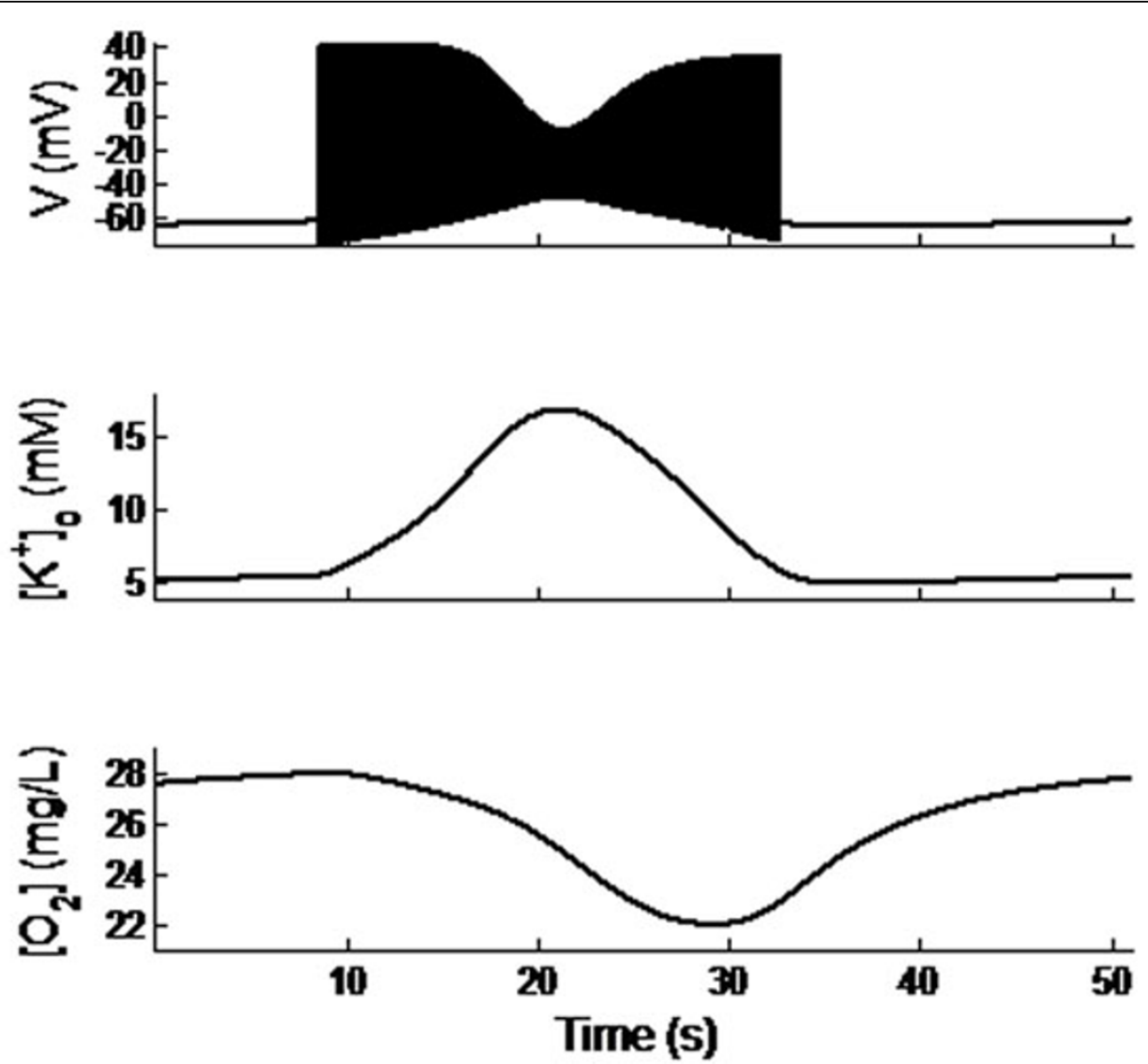

Figure 1 Membrane potentials (top trace), extracellular potassium concentration (middle trace), and oxygen density (bottom trace) from a single model neuron during a seizure event. The time course of $\left[\mathrm{O}_{2}\right]$ debt is qualitatively similar to that observed experimentally.

\footnotetext{
* Correspondence: yxw170@psu.edu

${ }^{1}$ Center for Neural Engineering, Department of Engineering Science and

Mechanics, Penn State University, PA 16802 USA

Full list of author information is available at the end of the article
} 
neurons is used by energetic $\mathrm{Na} / \mathrm{K}$-ATPase pumps that transport $3 \mathrm{Na}^{+}$outwards with $2 \mathrm{~K}^{+}$inward against their concentration gradients for each ATP hydrolyzed $[2,3]$. However, understanding the relationship between seizures and real-time oxygen dynamics has been restricted by current technical limitations. Computational models can offer insight to help understand the measurements from experiments.

We have performed experiments relating seizure activity at the cellular level with simultaneous real-time $\mathrm{O}_{2}$ microdomain measurements. In this paper, we build a mathematical neuron model that extends the HodgkinHuxley formalism containing leak currents for sodium, potassium and chloride ions, transient sodium currents, and delayed rectifier potassium currents. This neuron was embedded within an extracellular space and a simplified glia-endothelium system. The $\mathrm{Na}^{+}$and $\mathrm{K}^{+}$ion concentrations as well as extracellular oxygen density were continuously estimated. Hypoxia was modeled by reducing both neuron and glial $\mathrm{Na} / \mathrm{K}$-ATPase pump activities.

During seizure events, the extracellular $\mathrm{K}^{+}$and intracellular $\mathrm{Na}^{+}$were increased, which further activated the $\mathrm{Na} / \mathrm{K}$-ATPase pump activity. Energy (ATP) and $\mathrm{O}_{2}$ demand were simultaneously increased. Therefore, local available $\left[\mathrm{O}_{2}\right]$ decreased substantially during seizure events, and the apparent $\mathrm{O}_{2}$ debt substantially outlasts the intense electrical activity of a seizure, as shown in Figure 1. This result is consistent with experimental data [4]. We also observed that hypoxia alone can induce seizure like events, which occurs only in a narrow range of bath oxygen pressure, reflecting experimental observations. Lastly, we reproduced the interplay between excitatory and inhibitory neurons seen in experiments. Our model accounts for the different $\left[\mathrm{O}_{2}\right]$ levels that we have observed during seizures in pyramidal cell layers vs. inhibitory (oriens lacunosum moleculare) cell layers. Our work suggests the critical importance of modeling extracellular ion concentration and oxygen dynamics to properly understand the underlying mechanisms behind seizure and related phenomena.

\section{Author details}

${ }^{1}$ Center for Neural Engineering, Department of Engineering Science and Mechanics, Penn State University, PA 16802 USA. ${ }^{2}$ Theoretical Biology and Biophysics, Los Alamos National Laboratory, NM 87545 USA. ${ }^{3}$ Departments of Neurosurgery and Physics, Penn State University, PA 16802 USA.

Published: 16 July 2012

\section{References}

1. Attwell $D$, Laughlin SB: An energy budget for signaling in the gray matter of the brain. J Cereb Blood Flow Metab 2001, 21:1133.

2. Erecinska M, Dagani F: Relationship between the neuronal sodium/ potassium pump and energy metabolism. J Gen Physiol 1990, 95:591-616.
3. Lennie P: The cost of cortical computation. Current Biology 2003, 13:493-497.

4. Bahr S, Suh M, Zhao M, Schwartz TH: Intrinsic optical signal imaging of neocortical seizures: the'epileptic dip'. NeuroReport 2006, 17:499-503.

doi:10.1186/1471-2202-13-S1-O20

Cite this article as: Wei et al:: Oxygen dynamics during in vitro seizures. BMC Neuroscience 2012 13(Suppl 1):O20.

\section{Submit your next manuscript to BioMed Central} and take full advantage of:

- Convenient online submission

- Thorough peer review

- No space constraints or color figure charges

- Immediate publication on acceptance

- Inclusion in PubMed, CAS, Scopus and Google Scholar

- Research which is freely available for redistribution

Submit your manuscript at www.biomedcentral.com/submit
C Biomed Central 